\title{
Prejudice to the Environmental Balance Exacerbate the Outbreak of Zoonotic Cutaneous Leishmaniasis after the War against Daesh in - Al-Ramadi, Al-anbar Governorate
}

\author{
Amal H Atiyah* and Faraj Hato Joni \\ Institute of Medical Technology, Iraq \\ *Corresponding author: Amal H. Atiyah, Assist prof. Institute of medical Technology- Baghdad, MTU, Baghdad, Iraq. \\ To Cite This Article: Amal H. Atiyah. Prejudice to the Environmental Balance Exacerbate the Outbreak of Zoonotic Cutaneous Leishmaniasis \\ after the War against Daesh in - Al-Ramadi, Al-anbar Governorate. Am J Biomed Sci \& Res. 2019 - 3(5). AJBSR.MS.ID.000707. \\ DOI: 10.34297/AJBSR.2019.03.000707
}

Received: June 08, 2019 | Published: July 03, 2019

\begin{abstract}
Pollution resultant from military operations after the war against Daesh that happened in Ramadi city have direct or indirect significant impact, on contaminated of environmental elements which start to exacerbation the outbreaks of zoonotic Leishmaniasis. In view of the fact that is one of the interpretations of the negative consequences on society, combined with bad personal hygiene. The distribution of CL has explicit affected by demographic characteristics as well as climatic changes. Age group, type of construction, seems to have significant effect on morbidity with parasite. Incidence fluctuated according to degree of temperature during seasonal period a cutaneous leishmaniasis lesion observed in many parts of body's patients. However, a difference in the percentage of skin infestations was note, including face, hand, and arm and leg. Actually, the exact health situation in area's study is more complex and cannot be given based on a restricted data.
\end{abstract}

Keywords: Zoonotic; Prejudice; Leishmaniasis; Daesh; Cutaneous leishmaniasis; Environmental; Ramadi; War; Iraq

\section{Introduction}

Not only in third world countries but also worldwide, the problem of environmental pollution has become one of the most serious problems facing a human. Seriously get when decomposes nature's elements that have been in an unnatural way. Iraq suffers for many years from major disasters, thus demonstrated the complexity of development a wide variety of negative effects, problems and several diseases, such Leishmaniasis. It is zoonosis Protozoa disease [1,2], transmitted from reservoir hosts via bite of adult sand fly and perhaps affected Some 70 animal species, including man where living in the vicinity $[3,4]$. However, Leishmaniasis is classified as; a neglected tropical disease NTD [5]. Cutaneous form (CL) is the most common, caused by Leishmania tropica and L. major, globally distribution [6]. Cases of this disease in US service personnel have follow military activities in Iraq and Afghanistan [7]. In Iraq WHO, revealed 2978 and 2486 infected cases during 2011 and 2012, respectively. Like other cities of Iraq Ramadi, the capital of Anbar governorate entered the war against Daesh, resultant destruction at all levels, and tens of reports about complexity environmental issues. From this point, the objectives of our study were to assay the prevalence of Leishmaniasis in the Ramadi city resultant from created conditions associated with increased environmental pollution after war.

\section{Materials and Methods}

In Arabic: ( 国国目目回) Ar-Ramādī; also formerly rendered as Rumadiyah or Rumadiya),representing almost one-third of the size of Iraq, about 110kilometers west of Baghdad. It is the capital and the largest city of "Al Anbar" Province. The city is one of the most famous cities in Iraq, gained significant prosperity due to strategic location on the Euphrates and the road west into "Syria and Jordan" [8,9]. A desert climate have most rain falls in the winter [10]. The average annual temperature in Ramadi is $22.4^{\circ} \mathrm{C}\left(72.3^{\circ} \mathrm{F}\right)$. This city has been fought extend several times, during the two world wars and again during military campaign (2015-2016) against Daesh which led to escape of thousands of Iraqis from the city of Ramadi $[8,9,11]$. The study done in cooperation with information 
system / Anbar Health Directorate, were a questionnaire applied on randomly selected data from population who lives in refugee camps or returned to their houses destroyed during the fighting. Concerning sanitations level and affairs of families with respects of medical services that coverage the study area as shown in the Table 1. Statistical analysis was used for analyzed data was evaluated by SPSS version 14.0. The significance calculated at the level $\mathrm{p}<0.05$.

Table 1: Show the Items of the Questionnaire Used in the Present Study.

\begin{tabular}{|c|c|c|}
\hline Medical conditions & & No. $(\%)$ \\
\hline \multirow{2}{*}{ Prevention measures } & Yes & \\
\hline & No & \\
\hline \multirow{2}{*}{ Are there any previous infection? } & Yes & \\
\hline & No & \\
\hline \multirow{2}{*}{$\begin{array}{l}\text { Have previous infection been covered by any preven- } \\
\text { tive measures (spraying, fogging, fuming of rodent) }\end{array}$} & Yes & \\
\hline & No & \\
\hline \multirow{2}{*}{ Are there animals in the house? } & Yes & \\
\hline & No & \\
\hline \multirow{2}{*}{ Are there rodents at home? } & Yes & \\
\hline & No & \\
\hline \multirow{2}{*}{ Are there rodents around the home? } & Yes & \\
\hline & No & \\
\hline \multirow{2}{*}{ Have rodents been caught? } & Yes & \\
\hline & No & \\
\hline \multirow{2}{*}{$\begin{array}{l}\text { Have been investigation of insect in patient's house or } \\
\text { area? }\end{array}$} & Yes & \\
\hline & No & \\
\hline \multirow{2}{*}{ Is the infection locally or imported? } & Yes & \\
\hline & No & \\
\hline Have ever sprayed the house? & Yes & \\
\hline What kind: (partial or complete & No & \\
\hline \multirow{2}{*}{ Is the home close to animal barn? } & Yes & \\
\hline & No & \\
\hline \multirow{2}{*}{$\begin{array}{l}\text { Is the region covered by the distribution of mosquito } \\
\text { nets? }\end{array}$} & Yes & \\
\hline & No & \\
\hline \multirow{2}{*}{ Are the poultry fields close to patient's house } & Yes & \\
\hline & No & \\
\hline \multirow{2}{*}{$\begin{array}{l}\text { Are there residues in place of breeding insect and } \\
\text { rodents? Building rubble, garbage piles, etc }\end{array}$} & Yes & \\
\hline & No & \\
\hline \multirow{2}{*}{ Is there waterway? } & Yes & \\
\hline & No & \\
\hline \multicolumn{3}{|l|}{$\begin{array}{l}\text { What type of diagnosis? } \\
\text { Clinical Laboratory }\end{array}$} \\
\hline Is the treatment topical or Systemic & & \\
\hline
\end{tabular}

\section{Results}

Irrespective of the tested conditions, the average of the calculation was found by (205) infected cases. This value varied slightly with regard to the gender variable, included male $(52.68 \%)$ compared to females (47.32\%) but no significant value $\mathrm{P}>0.05$. Whereas significantly differences observed according to age group, the highest percentage of parasite positive (31.71\%) at age group ranged from 19-25 years and the lowest percentage in less than one year and (1-7) years $(0.98 \%)$ and $(3.41 \%)$ respectively. The highest percentage among housewife (34.63\%) and less percentage among teacher $(5.37 \%)$ for occupations mentioned above respectively, other has gradually from free work to students, then finally children (Table 2). 
Table 2: Shows the demographical features of infected cases.

\begin{tabular}{|c|c|}
\hline Demographical features & No. of infected cases (\%) \\
\hline \multicolumn{2}{|c|}{ Sex } \\
\hline Male patients & $108(52.68)$ \\
\hline Females patients & $97(47.32)$ \\
\hline Total patients & $205(100)$ \\
\hline \multicolumn{2}{|c|}{ Male/female ratio } \\
\hline \multicolumn{2}{|c|}{ Patient's age groups } \\
\hline less than 1 year & $2(0.98)$ \\
\hline 7-Jan & $7(3.41)$ \\
\hline $7-13$ & 33 (16.09) \\
\hline 13- 19 & $61(29.76)$ \\
\hline $19-25$ & $65(31.71)$ \\
\hline $25 \geq$ years & $37(18.05)$ \\
\hline Total & $205(100)$ \\
\hline \multicolumn{2}{|c|}{ The occupation of patients } \\
\hline Housewife & $71(34.63)$ \\
\hline Children & $20(9.76)$ \\
\hline Students & 35 (17.07) \\
\hline Teacher & $11(5.37)$ \\
\hline Free work & $68(33.17)$ \\
\hline Total & $205(100)$ \\
\hline
\end{tabular}

Concerning areas and residency, type of construction, seems or destruction houses were associated with highest morbidity to have significant effect on morbidity with parasite. Therefore, data obtained showed that people who lived in Brick and mud (56.59\%), while in Tent (43.41\%) (Table 3).

Table 3: Shows type of construction of infected house.

\begin{tabular}{|c|c|}
\hline House & Frequency (\%) \\
\hline Tent & $89(43.41)$ \\
\hline Brick and other & $116(56.59)$ \\
\hline Total & $205(100)$ \\
\hline
\end{tabular}

Table 4: Shows percentage of monthly morbidity of cutaneous leishmaniasis.

\begin{tabular}{|c|c|}
\hline Month/year & Infection rate (\%) \\
\hline Apr-16 & $5(2.44)$ \\
\hline May & $7(3.41)$ \\
\hline June & $7(3.41)$ \\
\hline July & $6(2.92)$ \\
\hline August & $9(4.39)$ \\
\hline September & $15(6.67)$ \\
\hline October & $18(8.78)$ \\
\hline November & $25(12.19)$ \\
\hline December & $25(12.19)$ \\
\hline Jan-17 & $15(6.67)$ \\
\hline February & $18(8.78)$ \\
\hline March & $20(9.75)$ \\
\hline April & $20(9.75)$ \\
\hline May & $20(9.75)$ \\
\hline Total & $205(100)$ \\
\hline
\end{tabular}


Incidence of CL fluctuated according to degree of temperature during seasonal period and from day to night to obtain the data on study sample. It appeared significantly affect $\mathrm{P}>0.05$ in November and December (12.19\%) both for each, compared to April, July 2016 and their percentage $(2.44 \%)$ and $(2.92 \%)$ respectively. Moreover, irrespective of tested temperature, there was a significant increase in the percentage of morbidity due to environmental pollution, during the first months of 2017, March, April and May (9.75\%) for each as compared with percentage recorded during 2016 (Table 4).

\begin{tabular}{|c|c|c|c|}
\hline Sex & & The site of skin lesion & Frequency (\%) \\
\hline \multirow{3}{*}{ Females } & \multirow{3}{*}{97} & Face & $43(20.98)$ \\
\hline & & Hand & $21(10.24)$ \\
\hline & & Both leg & $20(9.76)$ \\
\hline \multirow{3}{*}{ Males } & \multirow{3}{*}{108} & Face & $46(22.44)$ \\
\hline & & Hand & $31(15.12)$ \\
\hline & & Arm & $14(6.83)$ \\
\hline \multirow{2}{*}{ Total } & \multirow{2}{*}{205} & \multirow{2}{*}{ Right leg } & $30(14.63)$ \\
\hline & & & $205(100)$ \\
\hline
\end{tabular}

Table 6: The number of skin sores in patients according to sex.

\begin{tabular}{|c|c|}
\hline Site of infection & No. of boil \\
\hline \multicolumn{2}{|c|}{ Female } \\
\hline Face & 2-Jan \\
\hline Hand & 1 \\
\hline Both leg & 2 \\
\hline \multicolumn{2}{|c|}{ Males } \\
\hline Face & 3 \\
\hline Hand & 1 \\
\hline Arm & 2 \\
\hline Right leg & 3-Jan \\
\hline
\end{tabular}

A cutaneous leishmania sislesion observed in many parts of body's patients. However, a difference in the percentage of skin infestations noted, including face, hand, and arm and leg (Table 5). The skin lesion appeared high at face for females (1-2) and males at face and right leg 3 and 1-3 respectively compared to other site of body (Table 6). There was a significant correlation between the numbers of skin abrasions and present dead or alive parasite at the site of infection.

\section{Discussion}

Answers all items of questionnaire as shown in Table 1, leave negative impression, at the time of preparation the present study. As resultant from military operations after the War against Daesh, either direct or indirect have a significant impact for leaving population suffered from unsuitable housing, poorest sanitation and nutrition, in addition to environmental pollution, which led to prejudice of the natural ecological balance and exacerbates the outbreaks of Leishmaniasis. Globally further than five million persons deadly each year because varies diseases or events related to environmental pollution [12]. Studies done in Iraq during 2004 until 2008 demonstrated that 1,655 and 1,711 individuals have infected with CL and VL respectively. It was $<1$ per ten thousand among these infected cases found in A-Anbar province. 217 cases were diagnosed with L. during the first three months of 2014 [1315].

Concerning the infected persons, the actual number fails to report fully, it may significantly higher than were recorded. Knowing there are many infections not disclosed for several reasons. The review of literature identifies only $20 \%$ recorded. Males outnumbered females $108(52.68 \%)$ vs. $97(47.32 \%)$. the male sex more susceptible to infection than female because more exposed to the vector than female; perhaps linked with socioeconomic status [16]. These results agree with [17] have suggested that women have lower exposure to parasite $7(38.89 \%)$ compared to men $11(61.11 \%)$. Similarly, previous work has demonstrated that CL infections were more prone to develop in males because of more social activity and interaction with internally displaced persons, whereas females always remain covered because Islamic rules and thus are less prone to sand fly bites [16]. Moreover, higher percentage of infection (31.71\%) at age group 20-27 years. However, data obtained have demonstrated that age groups were independent factor associated with positive parasitic infection. Young are more susceptible to the infection than adult is. Previous work has noted least $70 \%$ of infected cases were children, aged 0-18 years [13]. In Mediterranean 1-4 years more susceptible, in china from 4-10 years, in India adult 20-26 years is corresponding to our study. Studies on epidemiology of CL outbreak in waraffected Waziristan areas, showed youths (1-15 of age) were more susceptible [18]. Regardless of the occupation, our results showed homemaker and free work were higher percentages of exposure to the parasite $(34.63 \%)$ and $(33.17 \%)$ respectively. With respect (Table 4) results, showed the number of CL were the higher (12.19\%) during November and December, these results interpret; abundant cases of disease In Iraq be found in November, December and January after incubation period. Elsewhere the report of WHO, were revealed that the ZCL in Iraq between December and March. Anyhow epidemiological scheme varies in various from region of the world. Shed light on role of temperature, highest infection occurs at low temperature. The Warm and moderate weather; improve the opportunities to raise give new cases of disease, in both agricultural area, and cities indoors [3] and outdoors [19]. A variable results demonstration great impact of ecological, physiological and behavioral factors on the incidence.

At that time after the war against Daesh, the bettering control measurement and surveillance act as great challenge for repairing and rehabilitation infrastructure [14]. Regarding skin lesion, the highest number laid on the face for both sexes. While previous work recorded, greatest case lesions based particularly at the limbs, in addition to faces and even mucosa [17]. These differences due to influence of the host, were the insect bite the exposed parts of the body. A study done by [18] showed that 11 of 18 patients had only one lesion, mostly on the face.

\section{Conclusion}

War directly related on the disrupting of basic infrastructure. The disease is capable of linked with natural ecological system 
imbalance, synergistic with bad personal environmental hygiene. Actually, the exact health situation in area's study is more complex and cannot give based on a restricted data. To stay the complex relationship between life and non-life within the ecosystem is stable as a way for perfect balance of the universe. CL more prevalent in study area and new cases are increasing day-by-day resultant from both disease and environmental pollution.

\section{References}

1. AA Akhavan, MR Yaghoobi E, D Mehdipour, Homa Hajjaran, H Abdoli, et al. (2003) Epidemic Outbreak of Cutaneous Leishmaniasis due to Leishmania major in Ghanavat Rural District, Qom Province, Central Iran. Iranian Journal of Public Health 32(4): 35-41.

2. Abaii MA, Rassi Y, Imamian H, Fateh M, Mohebali M, et al. (2007) PCR Based on Identification of Vectors Of Zoonotic Cutaneous Leishmaniasis in Shahrood District, Central of Iran. Pak J Biol Sci 10(12): 2061-2065.

3. Quaesma PF, Rego FD, Botelho HA, da Sliva SR, Moura Júnior AJ, et al (2011) Wild, synanthropic and domestic hosts of Leishmania in an endemic area of cutaneous leishmaniasis in Minas Geraia State, Brazil. Trans R Soc Trop Med Hyg 105(10): 579-585.

4. Leishmaniasis Fact sheet (2018) World Health Organization.

5. Neglected Tropical Diseases (2011) Which diseases are considered neglected tropical diseases?

6. Hussain M, Munir S, Jamal MA, Ayaz S, Akhoundi M, et al. (2017) Epidemic outbreak; of anthroponotic cutaneous leishmaniasis in Kohat District, Khyber Pakhtunkhwa, Pakistan. Acta Trop 172: 147-155.

7. Barbara L, Herwaldt, Alan J Magill (2018) Infectious Diseases Related to Travel, Leishmaniasis, Cutaneous Leishmaniasis, Cutaneous - Chapter 3 - 2018 Yellow Book. Center for disease control and prevention.
8. Ramadi (2018) Stadt-alpha.

9. Ramadi (2015) Iraqi Army Says; It Has Retaken City of Ramadi from ISIS. Huffington Post, Reuters, UK.

10. Peel MC, Finlayson BL, McMahon TA (2007) Updated world map of the Köppen-Geiger climate classification. Hydrol Earth Syst Sci 11: 16331644.

11. Ministry of Transportation Iraqi, Iraqi Meteorological Organization and Seismology.

12. World Health Organization (2014) Leishmaniasis Fact sheet N375..

13. Alawieh A, Musharrafieh U, Jaber A, Berry A, Ghosn N, et al. (2014) Revisiting leishmaniasis in the time of war: the Syrian conflict and the Lebanese outbreak. Int J Infect Dis 29: 115-119.

14. Leishmaniasis Fact sheet (2014) World Health Organization.

15. Alvar J, ID Vélez, C Bern, M Herrero, P Desjeux, et al. (2012) Leishmaniasis worldwide and global estimates of its incidence. PLoS One 7(5): e35671.

16. (2017) Three Reasons Poverty Contributes to the Top Diseases in Iraq.

17. Abbas Doroodgar, Mahbobi Saeid, Nemetian Mahmood, Masoud Doroodgar, M Sayyah (2009) An epidemiological study of cutaneous leishmaniasis in Kashan (2007-2008). Koomesh 10(3): 177-184.

18. Mubashir Hussain, Shahzad Munir, Taj Ali Khan, Abdullah Khan, Sultan Ayaz, et al. (2018) Epidemiology of Cutaneous Leishmaniasis Outbreak, Waziristan, Pakistan. Emerg Infect Dis 24(1): 159-161.

19. IIsabelle Arzul, Ryan B Carnegie (2015) New perspective on the haplosporidian parasites of molluscs. J Invertebr Pathol 131: 32-42. 